Note

\section{Adsorption Specificity of Immobilized Tannin for Proteins and Other Organic Compounds}

\author{
Taizo Watanabe, Takao Mori, \\ Tetsuya Tosa and Ichiro ChIBATA \\ Department of Biochemistry, \\ Research Laboratory of Applied Biochemistry, \\ Tanabe Seiyaku Co., Ltd., \\ 16-89, Kashima 3-chome, \\ Yodogawa-ku, Osaka 532, Japan
}

Recejved September 12, 1980

As protein adsorbents, there are many organic and inorganic compounds. However, they do not necessarily satisfy all the basic requirements for their uses. For example, they are not specific for proteins but adsorb yarious organic and inorganic compounds together with proteins. Accordingly, proteins recovered from an aqueous solution by these adsorbents are usually contaminated with impurities such as nucleic acids, heavy metals and pigments other than protein. Further, when these adsorbents are used for the removal of unfavorable proteins in a beverage such as Japanese saké or beer, various useful compounds related to taste, flavor, color are also removed, and the quality is lowered.

Therefore, we intended to prepare an adsorbent having high capacity and high adsorption specificity for proteins, and found that tannin covalently bound to aminohexyl cellulose-immobilized tannin-was favorable. ${ }^{1,2.57}$ We also investigated the characteristics and applications of this immobilized tannin, and found this adsorbent was useful as a tool for the recovery and purification of proteins $^{2)}$ and for the immobilization of enzymes. ${ }^{2 \sim 4 \text { ) }}$ Further, this adsorbent was promissing for improving the quality of beverages such as Japanese saké ${ }^{6 \sim 9)}$ and beer by removal of undesirable protein constituents from the solution. For further development of the application of this adsorbent, it was necessary to know well the adsorption specificity for a variety of compounds. So, we clarified the adsorption specificity in other papers ${ }^{1.5}$ for proteins, especially for enzymes, and organic compounds. In this paper, additional study was carried out to clarify the adsorption specificity of this adsorbent for proteins and compounds other than those tested previously.

Experiments were carried out as follows. Immobilized tannin (150 mg wet weight) prepared with epichlorohydrin $^{5,8)}$ was incubated with $10 \mathrm{ml}$ of a buffer solution containing a protein $(0.25 \mathrm{mg} / \mathrm{ml}$ buffer solution) or a compound $\left(0.1 \mathrm{mg} / \mathrm{ml}\right.$ buffer solution) at $5^{\circ} \mathrm{C}$ for $10 \mathrm{~min}$ with shaking. Buffer solutions used were $0.01 \mathrm{~m}$ sodium acetate-hydrochloric acid $(\mathrm{pH} 4.0), 0.01 \mathrm{M}$ disodium phosphate-sodium biphosphate $(\mathrm{pH} \quad 7.0$ ) and $0.01 \mathrm{M}$ sodium carbonate-hydrochloric acid ( $\mathrm{pH} 10.0)$. After the reaction, the mixture was filtered and immobilized tannin was washed with $10 \mathrm{ml}$ of the same buffer. The amount of proteins or various compounds adsorbed on immobilized tannin was calculated from the difference between the amount of the compounds in the initial solution and that in the filtrate and washing. Amino acids and Val-Leu-Ser-Ala were measured by ninhydrin method ${ }^{10)}$ and sugar was determined by the method using phenol-sulfuric acid. ${ }^{11}$ Glucosamine was determined by the method of Rondle and Morgan. ${ }^{12}$ Glutatione was measured by the method of Tieze. ${ }^{13)}$ Caffeine, nicotine and nucleic acid related compounds were measured by optical density at $260 \mathrm{~nm}$. Protein was measured by the method of Lowry et al. ${ }^{141}$

The results obtained were shown in Tables I and II. As shown in Table 1 , sugars, amino acids, peptides, nucleic acid related compounds, organic acids and alkaloides were not adsorbed to immobilized tannin at any $\mathrm{pH}$ mentioned above. On the other hand, as shown in Table II, proteins were more or less adsorbed to immobilized tannin. The adsorption rate of proteins to immobilized tannin was affected by the $\mathrm{pH}$ of a protein solution, and the optimum $\mathrm{pH}$ for the adsorption depended on the kind of protein used. These results were the same as that obtained in the other experiment. ${ }^{5}$ The adsorption rate of some proteins such as wheat glutenin, zein, concanavalin $\mathrm{A}$ and gelatim was not so high even at optimum $\mathrm{pH}$. Optimum $\mathrm{pH}$ of proteins with high adsorption rate was $\mathrm{pH} 7.0$ except for protamine and wheat glutenin. The classification of

Table I. Summary of Compounds Not ADSORBED to Immobilized TANNIN

Classification Compounds tested

Sugars

Soluble starch, raffinose lactose, maltose, sucrose galactose, glucose, fructose ribose, arabinose, mannose xyrose, sorbose, glucosamine

Amino acids and peptides

Alanine, aspartic acid, histidine isoleucine, methionine, phenylalanine tyrosine, Val-Leu-Ser-Ala, gluthatione

$\begin{array}{ll}\text { Nucleic acid } & \text { Adenine, adenosine, AMP } \\ \text { related } & \text { guanine, guanosine, GMP } \\ \text { compounds } & \text { cytosine, cytidine, CMP } \\ & \text { uracil, uridine, UMP }\end{array}$

Others malic acid 
Table II. Adsorption of Various Proteins to Immobilized Tannin at Several pHs

\begin{tabular}{|c|c|c|c|c|c|}
\hline & \multirow{2}{*}{ Proteins } & \multicolumn{3}{|c|}{ Adsorption rate $(\%)^{a}$} & \multirow[b]{2}{*}{$\mathrm{pH} 10$} \\
\hline & & $\mathrm{pH} 2$ & $\mathrm{pH} 4$ & pH 7 & \\
\hline \multirow[t]{2}{*}{ Albumin } & Ovalbumin & - & 5.4 & 49.5 & 0 \\
\hline & Bovine serum albumin & - & 8.7 & 58.8 & 0 \\
\hline \multirow[t]{3}{*}{ Globlin } & Bovine $\beta$-lactogloblin & - & 18.9 & 75.0 & 5.1 \\
\hline & $\begin{array}{l}\text { Bovine serum } \\
\alpha \text {-globlin IV-1 }\end{array}$ & - & 24.0 & 83.4 & 27.5 \\
\hline & Concanavalin A & -- & 5.0 & 15.1 & 4.1 \\
\hline Glutelin & Wheat glutenin & 21.3 & 12.3 & - & - \\
\hline Gliadin & $\operatorname{Zein}^{b}$ & - & 13.8 & 8.4 & 4.8 \\
\hline Protamin & Salmon protamin & - & 9.6 & 55.9 & 94.0 \\
\hline Scleroprotein & Gelatin & - & 9.1 & 22.2 & 2.4 \\
\hline \multirow[t]{2}{*}{ Phosphoprotein } & Bovine milk casein & $\ldots$ & 42.9 & 52.2 & 31.2 \\
\hline & Soybean casein & - & 34.8 & 97.5 & 28.1 \\
\hline Chromoprotein & Bovine hemoglobin & - & 0 & 44.6 & 16.4 \\
\hline Glycoprotein & Gastric mucin & - & 27.6 & 58.8 & 25.4 \\
\hline \multirow[t]{5}{*}{ Enzymer } & $x$-Amylase & - & 69.1 & 43.3 & 0 \\
\hline & Glucoamylase & - & 26.4 & 51.2 & 0 \\
\hline & Lysozyme & - & 0 & 38.4 & 80.2 \\
\hline & Pepsin & - & 76.5 & 34.1 & 0 \\
\hline & Trypsin & - & 0 & 11.4 & 11.7 \\
\hline
\end{tabular}

a Protein adsorbed/Protein used $\times 100$

b Dissolved in $70 \%$ ethanol.

c In the case of enzymes, experiments were carried out at enzyme concentration of $1 \mathrm{mg} / \mathrm{ml}$.

proteins on the basis of the interaction with immobilized tannin was described in the other paper. ${ }^{5}$ Through this study, it was further clarified that immobilized tannin was a specific adsorbent for proteins and interaction with proteins depended on protein species. The adsorbents for proteins employed so far, such as alumina, charcoal, ionexchange celluloses, are not specific for proteins. Thus, this new adsorbent described in this paper is considered to overcome the disadvantages of conventional adsorbents for proteins.

Moreover, as it became lately clear that this adsorbent was able to adsorb specifically heavy metals in addition to proteins, we also investigated the adsorption of heavy metal ions on immobilized tannin. The application of immobilized tannin as an adsorbent for heavy metals will be reported in detail in the separate paper. ${ }^{15}$;

\section{REFERENCES}

1) T. Watanabe, Y. Matuo, T. Mori, R. Sano, T. Tosa and I. Chibata, J. Solid-Phase Biochem., 3, 161 (1978).
2) T. Watanabe, M. Fujimura, T. Mori, T. Tosa and I. Chibata, J. Appl. Biochem., 1, 28 (1979).

3) T. Watanabe, T. Mori, T. Tosa and I: Chibata, Biotechnol. Bioeng., 21, 477 (1979).

4) M. Ono, T. Tosa and I. Chibata, Agric. Biol. Chem., 42, 1847 (1978).

5) T. Watanabe, T. Mori, T. Tosa and I. Chibata, $J$. Chromatogr., 207, 13 (1981).

6) Y. Nunokawa, S. Mikami, T. Tosa and I. Chibata, Hakkokogaku, 55, 343 (1977).

7) Y. Nunokawa, S. Shiinoki and T. Watanabe, Hakkokogaku, 56, 776 (1978).

8) T. Watanabe, T. Mori, N. Sakata, K. Yamashita, T. Tosa, I. Chibata, Y. Nunokawa and S. Shinoki, Hakkokogaku, 57, 141 (1979).

9) Y. Nunokawa, O. Sekiguchi, T. Watanabe and T. Mori, J. Brew. Soc. Jpn., 74, 399 (1979).

10) N. G. Cadavid and A. C. Paladini, Anal. Biochem., 9, 170 (1964).

11) M. Dubois, K. A. Gilles, J. K. Hamilton, P. A. Rebers and F. Smith, Anal. Biochem., 28, 350 (1956).

12) C. J. M. Rondly and W. T. J. Morgan, Biochem. J., 61, 586 (1955). 
13) F. Tietze, Anal. Biochem., 27, 502 (1969).

14) O. H. Lowry, N. J. Rosebrough, A. L. Farr and R. J. Randall, J. Biol. Chem., 193, 265 (1951).
15) T. Mori, T. Watanabe, T. Tosa, I. Chibata, K. Iwano and Y. Nunokawa, J. Brew. Soc. Jpn., 76, 111 (1981). 